\title{
ФОРМИРОВАНИЕ ИНФОРМАЦИОННО-КОММУНИКАЦИОННОЙ КОМПЕТЕНТНОСТИ БУДУЩИХ ПРЕПОДАВАТЕЛЕЙ
}

\section{FORMATION OF INFORMATION AND COMMUNICATION COMPETENCE OF FUTURE TEACHERS}

\section{Yu. Bogdanova \\ D. Mukhamadieva}

Summary: The article considers the basics of the formation of information and communication competence of future teachers. The international and Russian documentation in the field of development of information and digital competence of teachers is analyzed.

Keywords: information and communication competence, teacher, higher education, Internet resources.
Богданова Юлия Зуфаровна

к.филол.н., дочент, Государственный аграрный университет Северного Зауралья, г. Тюмень

bogdanowa2907@mail.ru

Мухамадиева Диана Маратовна

к.филол.н., дочент, Тюменское высшее военно- инженерное командное училище имени А.И. Прошлякова, г. Тюмень

diana455104@mail.ru

Аннотация: В статье рассмотрены основы формирования информационнокоммуникационной компетентности будущих преподавателей. Проанализирована международная и российская документация в сфере выработки информационно-цифровой компетентности преподавателей.

Ключевые слова: информационно-коммуникационная компетентность, преподаватель, высшее образование, интернет-ресурсы.

Стоит отметить, что в формировании информационного сообщества качественное образование играет одну из основных ролей. При этом преподаватель выступает в одно и то же время и в качестве объекта, и в качестве проводника позитивных перемен [6]. Эффективно осуществлять образовательный процесс, обеспечивать ответственное использование средств цифровых технологий для управления информацией, коммуникации, создания контента способна лишь информационно грамотная личность. Именно поэтому формирование и развитие информационно-цифровой компетентности будущих специалистов образования является важной составляющей их профессиональной подготовки. Однако сейчас наблюдается некоторое несоответствие профессиональных компетенций педагогов вызовам цифрового общества.

\section{Анализ послеАних исследований и публикаший}

На современном этапе в образовательном пространстве для описания навыков и компетентности в сфере информационно-коммуникационных технологий параллельно используется ряд понятий, в частности «цифровая компетентность», «информационно-цифровая компетентность», «информационно-коммуникационная компетентность», «медиа-компетентность», «цифровая грамотность», «цифровая культура». Среди них наиболее употребляемым является понятие «информационнокоммуникационная компетентность» как способность человека применять информационно-коммуникационные технологии в жизни, учебе и работе, постоянно и автономно развивать их. 
Толкования сущности понятий «цифровая грамотность», «цифровая компетентность», «цифровая культура», определение их структуры, особенностей находим во многих трудах зарубежных и отечественных ученых. В исследованиях Н. Сороко, А. Спирина научно обоснован вопрос цифровой грамотности и информационнокоммуникационной компетентности человека. Работы А. Гриценчук, И. Иванюк, С. Литвиновой, И. Малицкой, Н. Морзе, А. Овчарук А. Кравчины посвящены проблеме оценки информационно-коммуникационной компетентности. Г. Лаврентьева, Р. Моцик, А. Никулочкина, Л. Петухова, А. Суховирский и другие освещают отдельные аспекты выработки информационно-коммуникационных компетенций.

Цель статьи - исследование природы информационно-цифровой компетентности будущих преподавателей, структуры ИКТ-компетентности педагогов, в основе которой лежит взаимодействие нескольких подходов (это технологическая грамотность, углубление и выработка знаний и др.) Задачи исследования: анализ международной и российской документации в области выработки информационно-цифровой компетентности преподавателей; обоснование возможности проведения организации веб-квеста, направленного на формирование и развитие информационно-цифровой компетентности будущих.

\section{Изложение основного материала}

Повышение уровня и качества знаний, формирование современных компетентностей, в частности умение добывать информацию, общаться на иностранных языках, подготовка к профессиям будущего являются основными задачами реформы образования конкурентоспособной страны. В образовательной среде компетентность исследуется как динамическое сочетание знаний, умений, навыков, образов мышления, точек зрения, системы ценностей, иных личностных характеристик. Также компетентность обуславливает способность индивида к эффективной социальной адаптации, реализации профессиональной и / или последующей образовательной деятельности [18].

Как показывает анализ научных источников, характерной особенностью современных образовательных тенденций в высшей школе является направленность на развитие профессиональных знаний и компетенций, творческой инициативы, конкурентоспособности, мобильности будущих специалистов, способности к самостоятельной умственной работе.

Тот факт, что акцент с получения нормативно закрепленных знаний, умений и навыков сместился на выработку у обучающихся готовности к совершению практических действий, использование полученного опыта эффективных действий при реализации образовательной деятельности и социальной практики, предусматривает компетентностный подход [4]. Такой подход обеспечивает высокий уровень готовности будущих специалистов образования к успешной деятельности в различных сферах общества. В то же время формирование и развитие у будущих педагогов информационно-цифровой компетентности приобретает особое значение.

Только компетентный в сфере информационнокоммуникационных технологий преподаватель может обеспечить системное, сквозное внедрение цифровых технологий в процессе изучения всех предметов, взаимодействие учащихся между собой и с педагогом, осуществление исследований, индивидуальное обучение. В то же время доступность и простота информационно-коммуникационных технологий способствуют широкому использованию их средств в образовательном процессе, поскольку они обеспечивают его интенсификацию, увеличивают скорость и качество восприятия, понимания и усвоения знаний.

В Концепции развития цифровой экономики и общества РФ на 2018-2020 годы [7] указано, что процесс обучения с внедрением цифровых технологий становится мобильным, дифференцированным и индивидуальным. Однако технологии не заменяют преподавателя, а придают ему новые возможности, позволяя вместе с обучающимся получать удовольствие от увлекательного процесса общения и познания, помогают ему автоматизировать значительную часть своей работы, высвобождая время для поиска, общения, самосовершенствования, индивидуальной работы с учащимися, обеспечивают обратную «связь, повышают эффективность управления образовательным процессом и образованием в целом. Поэтому сформированная информационно-цифровая компетентность будущего педагога позволяет ему в профессиональной деятельности принимать эффективные решения по использованию средств информационнокоммуникационных технологий в определенной ситуации,

В Рекомендациях Европейского Парламента и Совета Европы по формированию ключевых компетентностей для обучения в течение жизни [19] отмечено, что основу цифровой компетентности составляют базовые навыки по использованию средств информационно-коммуникационных технологий: использование компьютеров для поиска информации, ее анализ, хранение, выработки, презентация и обмен ею, а также для общения в социальных сетях в Интернете. Сейчас в сфере образовательных стандартов современным стратегическим документом, разработанным европейским сообществом, является Рамка цифровой компетентности для граждан (DigComp 2.0: Digital Competence Framework for Citizens) [7], которая определяет основные составляющие цифро- 
вой компетентности в пяти сферах (информация и цифровая грамотность, коммуникация и сотрудничество, создания цифрового контента, безопасность, решение проблем) по трем уровням (базовый, независимый, профессиональный пользователь).

Концептуальная эталонная модель цифровой компетентности педагога DigCompEdu, разработанная исследовательским центром Европейской Комиссии в 2017 году, ориентирована на специалистов всех уровней образования, от раннего детства к высшему образованию и образованию взрослых, включая общеобразовательную и профессиональную подготовку, обучение лиц с особыми потребностями и неформальное обучение. В международном стандарте «Структура ИКТ-компетентности учителей» [13], разработанном ЮНЕСКО совместно с ведущими экспертами в сфере ИКТ, определены компетентности педагогов, необходимые для эффективной организации обучения с использованием средств информационно-коммуникационных технологий. В ежедневной практике педагога реализация подхода технологической грамотности предусматривает:

- навыки использования средств цифровых технологий;

- умение выбирать и использовать готовое учебное или тренировочное программное обеспечение, игры и веб-содержимое;

- внедрения стратегий оценивания;

- умение применять ИКТ для управления образовательным процессом и для повышения своей квалификации.

Способность управлять информацией, структурировать задачи для решения проблем, сочетать универсальные и специализированные программные средства с совместными проектами, умение применять ИКТ для создания и мониторинга учебных проектов по различным учебным предметам, сотрудничества с другими преподавателями для повышения своего профессионального уровня - именно такая цель второго подхода углубление знаний. Преподаватель, который способен реализовать еще один подход - создание знаний, обеспечивает проектирование учебных ресурсов и среды на основе ИКТ с привлечением к этому своих учеников и коллег, внедрение цифровых технологий для развития у учащихся умения критически мыслить, постоянно и вдумчиво учиться.

Специалисты института информационных технологий и средств обучения охарактеризовали четыре уровня развития информационно-цифровой компетентности педагога: пользователь, тьютор, консультант и исследователь - и определили для каждого из них мотивационно-ценностный, когнитивно-операционный и рефлексивных-проектировочный компоненты.
Анализируя содержание информационно-цифровой компетентности, А. Спирин [14] предлагает определять шесть уровней развития компетентности:

- вводный, что предполагает понимание необходимости ИКТ для развития образования;

- минимально базовый, то есть умение пользоваться готовыми программными продуктами;

- базовый, на котором педагог демонстрирует знание и умение использовать основные понятия ИКТ в профессиональной деятельности;

- повышенный / углубленный, на котором педагог свободно применяет знания по ИКТ в профессиональной деятельности;

- исследовательский, т.е. свободное использование ИКТ, Интернет-ресурсов в исследовательской, проектной деятельности;

- экспертный - педагог является экспертом по вопросам внедрения ИКТ в образовательный процесс.

Согласно дескрипторам Национальной рамки квалификаций [14] приводим описание квалификационных уровней информационно-цифровой компетентности (табл. 1).

Анализируя пирамиду цифрового привлечения [5], убеждаемся, что формирование информационно-цифровой компетентности возможно при условии организации активной учебно-познавательной деятельности студентов, которая будет обеспечивать переход от пассивного получения знаний к познанию как активной деятельности. Это обеспечивается благодаря внедрению технологии «веб-квест», которая является актуальным объектом современного педагогического исследования. Анализ научных публикаций свидетельствует о высоком интересе педагогического сообщества к проблеме практического применения технологии «веб-квест». Однако вопрос значения и места веб-квестов в процессе формирования информационно-цифровой компетентности будущих педагогов требует дополнительного изучения.

В научной литературе нет единого теоретического подхода к формулировке понятия «веб-квест». Однако большинство исследователей отмечают [10], что в ходе выполнения учебных, поисково-познавательных, проблемных задач веб-квеста студенты учатся находить, обрабатывать, анализировать, систематизировать и представить необходимую информацию, решать поставленные задачи. Это способствует развитию мышления, профессиональных умений участников образовательного процесса, трансформации функций педагога в функции тьютора, фасилитатора.

Организация веб-квестов как самостоятельной познавательной деятельности будущих специалистов образования основывается на убеждении, что интегра- 
Таблица 1.

Описание квалификационных уровней компетентности

\begin{tabular}{|l|l|}
\hline знание & Знать: \\
& Интернет-источники; \\
программы MS Office (Word, Power Point, Microsoft Publisher, Excel); & готовые программные продукты в виде электронных учебных пособий, энциклопедий, словарей и пр.; \\
& методику применения ИКТ в образовательном процессе; \\
основные сведения об оборудовании ПК, правила техники безопасности, основы работы на компьютере, основные \\
программные средства (текстовые редакторы, базы данных, электронные таблицы, работа в сетях). \\
социальные сервисы Интернета
\end{tabular}

ция цифровых технологий в образовательный процесс способствует не только усилению мотивации студентов к обучению, созданию условий для самореализации и самоутверждения в близкой для них среде, поскольку студент XXI века является представителем цифрового поколения, но и формированию у них информационноцифровой компетентности.

Организуя веб-квест, преподаватель предлагает обучающимся задание и дает им конкретный план выполнения, ссылки на соответствующие Интернет-источники, таким образом помогая им найти нужные сведения и при этом формируя целостную картину поставленной задачи [1-3]. В процессе выполнения заданий студенты осуществляют процесс поиска необходимой информации, пользуясь Интернет-ресурсами, формулируют ответы и направляют их преподавателю в Google Forms или с помощью электронной почты. Полученная информация обобщается в форме буклета или презентации с помощью приложений MS Publisher, MS PowerPoint, Canva и др.

Одновременно с выполнением задач квеста студентам предлагается создавать папки с файлами не только на персональных компьютерах, но и в облачной среде, в частности в аккаунте Google, осуществлять резервное копирование файлов выполненных работ, обеспечивать доступ к ним на других устройствах: мобильном телефоне, планшете или компьютере в учебном кабинете, настраивать офлайновый доступ к аккаунту Google, использовать QR-код для быстрого доступа к нужному вебресурсу на смартфоне или планшете. Демонстрируется также практика применения в образовательном процессе различных веб-ресурсов с такой целью:

- для хранения медиафайлов, например, YouTube;

- для создания и хранения учебных материалов: онлайн-презентаций, карт знаний (ментальных карт), инфографики, интерактивных кроссвордов, тестовых сред и т.д. (LearningApps, Merlot II, Prezi, Moovly, PowToon, Thinglink, Bubbl.us, FreeMind, Gloster, Padlet, Rebus1 и др.)

- для совместной работы с различными документами (Google Docs, Google Maps Google Sites, Googleтаблицами и др.).

Внедрение технологии «веб-квест» способствует формированию информационно-цифровой компетентности будущих специалистов благодаря осознанию значения информационно-коммуникационных технологий для профессиональной деятельности и обучения в течение жизни, практическому применению знаний, умений, навыков для профессиональных и учебных целей, социальной взаимодействия.

\section{Выводы}

Профессиональная деятельность преподавателя состоит в том, что он адаптирует учащихся к новым для них информационно-коммуникационным технологиям и первым демонстрирует значение и преимущества информационно-коммуникационных технологий как орудия учебной деятельности. Используя возможности информационно-коммуникационных технологий, педагог побуждает учащихся к активному обучению, поощряет 
взаимодействия, сотрудничества, способствует формированию умений решать проблемы, создавать новые знания. Именно поэтому перед современной высшим образованием, стоит задача обеспечить личностное и профессиональное становление будущих преподавателей таким образом, чтобы уровень компетентности специалиста отвечал потребностям настоящего, позволил обеспечить качественное образование студентов.

\section{ЛИТЕРАТУРА}

1. Богданова Ю.3. Риторика как важная составляющая профессиональной подготовки студентов // Мир науки, культуры, 0бразования. - 2018. - № 5 (72). C. $413-414$.

2. Богданова Ю.З. Инновационные методы преподавания русского языка и культуры речи в неязыковом вузе // Перспективы науки. - 2019. - № 3 (114). C. 68-71.

3. Богданова Ю.3. Возможности online-образования в преподавании иностранных языков // Перспективы науки. - 2017. - № 11 (98). - С. $112-115$.

4. Бойчук Ю.Д. Компетентностный подход как методологическая основа реформирования отечественной современного высшего образования / Ю.Д. Бойчук, А.В. Турчинов // Ученые записки Крымского инженерно-педагогического университета. - 2014. - Выпуск 48. - (Серия «Педагогические науки»). C. 29-34.

5. Дорош Марина. Дети и технологии: «пирамида цифровой поведения» [Электронный ресурс] / Марина Дорош // Media Sapiens. - Режим доступа: https://ms.detector.media/mediaprosvita/kids/diti_i_tekhnologii_piramida_tsifro\%20voi_povedinki/.

6. Лаврентьева Г.П. Пропедевтика формирования информационной культуры учащихся в начальной школе / Г.П. Лаврентьева // Компьютер в школе и семье. - 2013. - № 8. - С. 3-8.

7. Литвинова С.Г. Информационно-коммуникационные компетентности учителей общеобразовательных учебных заведений / С.Г. Литвинова // Компьютер в школе и семье. - 2011. - № 5. - С. 6-10.

8. Моцик Р.В. Формирование готовности будущих учителей начальных классов использовать персональный компьютер как средство учебной деятельности: Автореф. дис. на получение наук. степени канд. пед. наук: спец. 13.00.04 «Теория и методика профессионального образования» / Р.В. Моцик. M., 2009. - $22 C$.

9. Никулочкина А.В. Развитие информационной компетентности учителя начальных классов в системе последипломного образования: дис. ... кандидата пед. наук: 13.00.04 / Никулочкина Елена Васильевна. - Запорожье, 2009. - 278 с.

10. Оценка информационно-коммуникационной компетентности учащихся и педагогов в условиях интеграционных процессов в образовании: пособие / Быков В.Ю., Овчарук А.В. и др. - М.: Педагогическая мысль, 2017. - 160 с.

11. Петухова Л.Е. Теоретико-методические основы формирования информатических компетентностей будущих учителей начальных классов: Дис. ... доктора пед. наук: 13.00 .04 / Л.Е. Петухова. - Херсон, 2009. - 564 с.

12. Сокол И.М. Подготовка учителей к использованию квест-технологии в системе последипломного образования: Дис. ... канд. пед. наук: 13.00 .04 / Сокол Ирина Николаевна. - Запорожье, 2016. - 284 с.

13. Сороко Н.В. Развитие информационно-коммуникационной компетентности учителей филологической специальности в условиях компьютерно ориентированной среды: Автореф. дис. на получение наук. степени канд. пед. наук: спец. 13.00.10 «Информационно-коммуникационные технологии в образовании» / В. Сороко. - М., 2012. - 20 с.

14. Спирин А.Н. Информационно-коммуникационные и информатические компетентности как компоненты системы профессионально-специализированных компетенций учителя информатики [Электронный ресурс] / А.Н. Спирин // Информационные технологии и средства обучения. - 2009. № 5 (13). - Режим доступа: http://eprints.zu.edu.ua/3733/2/09somtio.htm.

15. Структура ИКТ-компетентности учителей: рекомендации ЮНЕСКО [Электронный ресурс]. - Режим доступа: http://pond.if.ua/attachments/article/272/ rekomendacii_ikt.pdf.

16. Суховирский А.В. Подготовка будущего учителя начальной школы к использованию информационных технологий: Автореф. дис. на получение наук. степени канд. пед. наук: спец. 13.00.04 «Теория и методика профессионального образования» / В. Суховирский. - М., 2005. - 27 с.

17. Якстиене В. Согласованность ИКТ-компетенций учителя и учебных программ // Socialiniai mokslai. 2011. № 1 (71). С. 62-72.

18. Редекер К. Европейские рамки цифровой компетентности преподавателей: DigCompEdu. Пуни Ю. (ред.). EUR 28775 EN. Бюро публикаций Европейского союза, Люксембург, 2017 г., ISBN 978-92-79-73494-6, DOI: 10.2760 / 159770, JRC107466.

19. Вуорикари Р., Пуни Й., Карретеро Гомес С., Ванден Бранде, Г. (2016) DigComp 2.0: Структура цифровых компетенций для граждан. UpdatePhase 1: Концептуальная эталонная модель. Люксембургское издательство Европейского Союза. 27948 евро EN. DOI: 10.2791 / 11517/. 44 с. 